\title{
Pengembangan Model Evaluasi Stake Berbasis ANEKA-Tri Hita Karana dengan Pengkalkulasian $S A W$ dalam Penentuan Aspek-aspek Prioritas Perbaikan Mutu Belajar dan Karakter Siswa
}

\author{
Dewa Gede Hendra Divayana\#1 \\ ${ }^{\#}$ Program Studi Pendidikan Teknik Informatika, Universitas Pendidikan Ganesha \\ Jl. Udayana No. 11 Singaraja, Bali, Indonesia \\ 1hendra.divayana@undiksha.ac.id
}

\begin{abstract}
Abstrak-Model evaluasi yang dapat digunakan secara akurat untuk mengevaluasi mutu belajar dan karakter siswa pada SMK TI dan mampu memberikan rekomendasi yang tepat dengan menunjukkan aspek-aspek prioritas yang perlu disempurnakan, merupakan suatu inovasi baru yang menjadi kebutuhan dunia pendidikan di era revolusi industri 4.0 saat ini. Penelitian ini dilaksanakan dengan tujuan utama untuk mengetahui bentuk rancangan dari model evaluasi pendidikan yang menggabungkan model Stake, konsep ANEKA, konsep Tri Hita Karana dan metode SAW (Simple Additive Weighting) sebagai terobosan untuk menjawab kebutuhan dunia pendidikan terkait inovasi baru dalam pengembangan model evaluasi pendidikan. Metode yang digunakan dalam mengembangkan model evaluasi ini adalah metode Research \& Development $(R \& D)$ dengan desain Borg and Gall. Subjek yang dilibatkan pada uji coba rancangan dan simulasi perhitungan $S A W$ dalam penelitian ini sebanyak dua pakar pendidikan dan dua pakar informatika. Alat yang digunakan dalam pengumpulan data dalam penelitian ini berupa kuesioner dan foto dokumentasi. Teknik deskriptif kuantitatif digunakan untuk mengenalisis data yang terkumpul dalam penelitian ini. Hasil penelitian ini menunjukkan persentase efektivitas rancangan model evaluasi sebesar $89 \%$ sehingga dapat dikategorikan baik dan tidak perlu dilakukan revisi major jika ditinjau dari pengkonversian tingkat pencapaian efektivitas dengan skala lima.
\end{abstract}

Kata kunci-Model Evaluasi, Stake, ANEKA, Tri Hita Karana, SAW

\section{Pendahuluan}

Pada era kemajuan teknologi saat ini yang dibarengi dengan dicetuskannya revolusi industri 4.0, maka peran teknologi informasi sangatlah penting dan semakin jelas pengimplementasiannya dalam menunjang lini-lini kehidupan manusia. Semua aktivitas yang dilakukan oleh umat manusia dapat dibantu dan difasilitasi melalui kehadiran teknologi informasi. Berbagai bidang kehidupan mulai dari bidang industri rumah tangga sampai dengan industri dalam sekala besar, bidang pertanian, bidang pemerintahan, bidang pariwisata, bidang peternakan, dan bahkan di bidang pendidikanpun juga telah ditunjang dan difasilitasi dengan teknologi informasi.

Beberapa bentuk pemanfaatan teknologi informasi yang dapat membantu perkembangan proses pembelajaran dalam bidang pendidikan sebenarnya sudah diketahui sejak kemunculan model pembelajaran yang memanfaatkan komputer, seperti: CAI (Computer Assisted Learning), E-Learning (Electronic-Learning), dan CBI (Computer Based Instruction). Hal ini diperkuat dengan adanya pernyataan dari Usman [1] yang mengungkapkan bahwa "pengguanaan komputer dalam bidang pendidikan dapat dibagi menjadi dua bentuk, yaitu dalam bentuk Computer Assisted Instruction (CAI) dan Computer Based Instruction (CBI)".

Optimalisasi pemanfaatan teknologi informasi dalam proses pembelajaran tentu sangat dipengaruhi oleh kualitas dan kuantitas sarana yang memadai, seperti: ketersediaan komputer, jaringan komputer, internet, dan fasilitas penunjang lainnya yang mendukung terwujudnya pembelajaran berbasis teknologi informasi. Pada umumnya, sekolah-sekolah yang menerapkan proses pembelajaran berbasis teknologi informasi telah mampu menyiapkan sarana dan prasarana dengan standar minimum, seperti tersedianya komputer dan internet untuk dapat menyelenggarakan proses pembelajaran berbasis teknologi informasi. Apalagi, sekolah-sekolah yang memang merupakan sekolah bidang teknologi informasi, tentunya akan sangat optimal dalam mempersiapkan sarana dan prasarana penunjang proses pembelajaran berbasis teknologi informasi.

Namun di sisi lain, beberapa fakta sering terjadi dan memunculkan suatu temuan permasalahan saat pelaksanaan proses pembelajaran berbasis teknologi informasi, khususnya di sekolah-sekolah menengah kejuruan bidang teknologi informasi yang ada di daerah Bali. Permasalahan-permasalahan tersebut diantaranya: 1) 
ketergantungan pada internet, sehingga siswa malas mencari ide sendiri dalam memecahkan atau menjawab suatu kasus/pertanyaan yang ditanyakan oleh guru; 2) siswa berani melawan guru, karena melihat contoh-contoh yang tidak baik melalui informasi yang diperolehnya melalui internet; 3) kepercayaan siswa terhadap ilmu/materi yang ditransfer oleh guru menurun, karena siswa beranggapan bahwa semua materi ataupun informasi dapat mudah dicari secara langsung melalui internet; 4) para siswa sering menyalahgunakan fasilitas yang seharusnya digunakan untuk proses pembelajaran, namun mereka gunakan hanya untuk bermain game online; dan 5) kenakalan remaja, seperti: merokok, mabukmabukan, sex bebas, balapan liar mulai bermunculan akibat contoh-contoh dan informasi buruk yang mudah diakses melalui internet.

Berdasarkan fakta dan temuan tersebut, maka tentunya akan mempengaruhi karakter siswa dan mutu proses pembelajaran komputer di sekolah. Oleh karena itu, perlu dilakukan kegiatan evaluasi secara mendalam untuk memperoleh solusi pemecahan yang optimal. Pada intinya kegiatan evaluasi dilakukan untuk memperoleh suatu rekomendasi yang pantas digunakan dalam melakukan suatu perbaikan atau penyempurnaan terhadap suatu objek yang diamati. Hal ini sangat sesuai dengan konsep atau definisi evaluasi yang telah diungkapkan oleh beberapa peneliti, diantaranya: Sundayana pada tahun 2015 [2], Mahirah pada tahun 2017 [3], Prihaswati, dkk pada tahun 2017 [4], dan Gondikit pada tahun 2012[5], yang pada prinsipnya juga menyatakan hal yang sama yaitu hasil evaluasi berakhir pada ditemukannya rekomendasi yang pantas dan tepat digunakan sebagai acuan/dasar dalam memudahkan mengambil suatu keputusan bagi pihak pengambil keputusan atau kebijakan.

Kegiatan evaluasi sangat penting dilakukan untuk memperoleh rekomendasi terbaik yang nantinya diberikan kepada pihak pengambil kebijakan (dalam hal ini yaitu Kepala Sekolah) di masing-masing sekolah, khususnya pada sekolah bidang komputer yang mengalami masalah terkait pelaksanaan proses pembelajaran berbasis teknologi informasi, sehingga nantinya mutu dan karakter siswa yang mengikuti proses pembelajaran komputer dapat lebih memadai. Secara umum, terdapat beberapa model evaluasi yang dapat digunakan untuk mengevaluasi proses pembelajaran di sekolah, antara lain: model formative-summative, model CIPP, model evaluasi berorientasi pada tujuan, model evaluasi bebas tujuan, model countenance, model CSE-UCLA, dan model discrepancy.

Namun, jika dilihat dari temuan yang diperoleh, maka diperlukan suatu model evaluasi yang dapat digunakan untuk mengevaluasi karakter siswa dan mutu pembelajaran komputer di sekolah, terutama pada sekolah bidang teknologi informasi. Salah satu model yang dapat digunakan untuk mengevaluasi karakter siswa dan mutu proses pembelajaran komputer di sekolah yaitu model evaluasi Stake berbasis ANEKA-Tri Hita Karana yang terintegrasi dengan kalkulasi $S A W$. Model ini merupakan suatu pengembangan dari model evaluasi Stake yang dikombinasikan dengan konsep Tri Hita Karana dan proses kalkulasi penentuan rekomendasi menggunakan metode SAW (Simple Additive Weighting). Model Stake yang pada dasarnya memiliki dua matrix yaitu matrix deskripsi dan matrix pertimbangan. Model Stake tersebut kemudian dikembangkan dengan cara melakukan modifikasi terhadap dua matrix yang dimilikinya dengan menyisipkan konsep ANEKA dan Tri Hita Karana serta selanjutnya dilakukan proses penentuan rekomendasi untuk menunjukkan aspek-aspek prioritas yang harus diperbaiki menggunakan kalkulasi metode $S A W$.

Berdasarkan temuan dan terobosan model evaluasi yang dijelaskan di atas, maka rumusan permasalahan dalam penelitian ini adalah: 1) bagaimanakah bentuk rancangan model evaluasi Stake berbasis nilai ANEKA-Tri Hita Karana yang digunakan untuk mengukur karakter siswa dan mutu proses pembelajaran komputer pada SMK TI di Provinsi Bali?; 2) bagaimanakah hasil uji coba rancangan model evaluasi Stake berbasis nilai $A N E K A-T r i$ Hita Karana yang terintegrasi dengan kalkulasi $S A W$ ? 3) bagaimanakah simulasi perhitungan metode $S A W$ yang digunakan untuk menentukan aspek-aspek yang menjadi prioritas perbaikan karakter siswa. Dari rumusan permasalahan tersebut, maka tujuan penelitian ini adalah untuk mengetahui bentuk rancangan model evaluasi, hasil uji coba rancangan model evaluasi, dan simulasi perhitungan $S A W$ untuk menentukan aspek-aspek prioritas perbaikan karakter siswa dalam mengikuti pembelajaran komputer pada SMK TI di Bali.

Kehadiran penelitian ini karena dilatarbelakangi dari beberapa penelitian yang relevan, diantaranya: penelitian yang telah dilakukan oleh Lukum pada tahun 2015 [6] tentang evaluasi program pembelajaran IPA SMP menggunakan model Countenance Stake yang ternyata memiliki persamaan dengan penelitian yang penulis lakukan dalam hal penggunaan model Stake dalam mengevaluasi proses pembelajaran, namun perbedaannya terletak pada objek yang dievaluasi, dimana objek evaluasi yang dilakukan Lukum adalah program pembelajaran IPA SMP sedangkan penulis dalam penelitian ini mengevaluasi tentang karakter siswa dan mutu/kualitas pembelajaran komputer. Adapun temuan dalam penelitian evaluatif yang dilakukan oleh Lukum yaitu hasil evaluasinya menggambarkan adanya ketidakmampuan siswa dalam menunjukkan kualitas pembelajaran yang baik karena hasil belajar mereka belum memenuhi standar kriteria ketuntasan minimal dan ketidaksesuaian antara RPP (Rencana Pelaksanaan Pembelajaran) dengan standar proses pembelajaran yang ditetapkan.

Penelitian tentang aktualisasi nilai ANEKA pada profesi dosen IHDN Denpasar sebagai dasar komitmen mutu pelayanan publik yang telah dilakukan pada tahun 2016 oleh Oktarina [7], memiliki persamaan dengan penelitian ini yaitu dalam hal pengaktualisasian atau penginternalisasian konsep ANEKA ke dalam objek yang diteliti. Perbedaannya terletak pada pendekatan 
penelitiannya, dimana penelitian yang dilakukan oleh Oktarina adalah pendekatan kualitatif, sedangkan penelitian ini menggunakan pendekatan pengembangan. Kendala yang ditemukan dalam penelitian yang dilakukan Oktarina adalah hasil penelitiannya menunjukkan aktualisasi $A N E K A$ yang lebih cenderung hanya berfokus pada komitmen mutu.

Penelitian yang dilakukan oleh Retnowati, dkk mulai tahun 2017 tentang model evaluasi kinerja dosen yang berfokus pada pengembangan instrumen untuk mengevaluasi kinerja dosen [8], memiliki persamaan dengan penelitian ini dalam hal pendekatan penelitiannya yaitu penelitian evaluatif. Perbedaannya terletak pada fokus penelitian, dimana dalam penelitian yang dilakukan penulis lebih fokus pada pengembangan model evaluasi, sedangkan penelitian Retnowati, dkk lebih fokus dalam pengembangan instrumen evaluasi. Kendala yang masih ditemukan dalam penelitian yang dilakukan oleh Retnowati, dkk adalah hanya terbatas pada empat aspek yang digunakan untuk mengevaluasi kinerja dosen.

Penelitian yang dilakukan pada tahun 2015 oleh Sugiyanto, Kartowagiran, dan Jailani [9] tentang pengembangan model evaluasi proses pembelajaran Matematika di SMP berdasarkan kurikulum 2013 memiliki persamaan dengan penelitian ini dalam hal pendekatan penelitian yang digunakan yaitu penelitian evaluatif. Perbedaannya terletak pada bentuk model yang dikembangkan, dimana pada penelitian ini mengembangkan model Stake yang dimodifikasi dengan konsep ANEKA, konsep Tri Hita Karana, dan penyisipan perhitungan metode $S A W$, sedangkan pada penelitian yang telah dilakukan oleh Sugiyanto, Kartowagiran, dan Jailani mengembangkan model evaluasi yang didasarkan pada kurikulum 2013. Kendala yang ditemukan pada penelitian Sugiyanto, Kartowagiran, dan Jailani tersebut adalah belum mampu mengevaluasi karakter siswa dan mutu kemampuan kognitif siswa dalam mengikuti proses pembelajaran.

Penelitian yang dilakukan pada tahun 2015 oleh Basuki [10] tentang efektifitas implementasi diklat prajabatan kategori I dan II sesuai peraturan kepala LAN nomor 18 tahun 2014 memiliki persamaan dengan penelitian ini dalam hal fokus kajiannya tentang konsep ANEKA, namun perbedaannya terletak pada efektivitas keberhasilan implementasi ANEKA dalam proses pembelajaran, dimana pada penelitian yang dilakukan oleh Basuki ditemukan kendala berupa penginternalisasian nilai-nilai $A N E K A$ oleh sebagian besar CPNS Kategori 1 dan kategori 2 (K1/K2) dalam melaksanakan tupoksinya belum berhasil dijalankan secara optimal dan menyeluruh, sedangkan pada penelitian ini evaluasi dilaksanakan secara optimal agar konsep nilai-nilai ANEKA dapat diinternalisasi secara menyeluruh ke dalam matrix deskripsi yang terdapat pada model evaluasi Stake, sehingga hasil evaluasi dapat menjadi rekomendasi yang tepat untuk penyempurnaan proses pembelajaran.

Berdasarkan rumusan permasalahan, terobosan awal untuk penyelesaian masalah, serta beberapa kajian penelitian yang mendasari kehadiran penelitian ini, maka penulis tertarik melaksanakan penelitian dengan topik yaitu "pengembangan model evaluasi Stake berbasis ANEKA-Tri Hita Karana dengan perhitungan metode $S A W$ dalam menentukan aspek-aspek yang menjadi prioritas perbaikan mutu belajar dan karakter siswa SMK TI di Provinsi Bali ".

\section{Metode Penelitian}

Penelitian ini dilaksanakan selama tiga tahun, menggunakan metode penelitian dan pengembangan, dengan desain model Borg and Gall. Mengacu pada tujuan penelitian yang telah dijelaskan sebelumnya pada latar belakang, maka dalam tulisan ini hanya fokus menjelaskan tahapan rancangan model evaluasi, tahapan uji coba rancangan model evaluasi, dan tahapan simulasi perhitungan $S A W$. Tempat pelaksanaan penelitian ini dilaksanakan pada beberapa SMK bidang teknologi informasi yang ada di provinsi Bali.

Kurang lebih dibutuhkan waktu selama 42 hari untuk dapat menyelesaikan rancangan model evaluasi Stake berbasis nilai ANEKA dan Tri Hita Karana, yang dimulai dengan aktivitas penentuan komponen evaluasi sampai dengan rancangan model yang siap untuk di uji coba. Subjek yang terlibat dalam melakukan uji coba terhadap rancangan model evaluasi Stake berbasis nilai ANEKA dan Tri Hita Karana yang telah terbentuk adalah sebanyak empat pakar, antara lain: dua orang pakar teknik informatika dan dua orang pakar evaluasi pendidikan.

Instrumen pengumpulan data yang digunakan dalam penelitian ini yaitu berupa foto dokumentasi dan kuesioner. Foto dokumentasi digunakan untuk merekam tampilan desain model evaluasi Stake berbasis nilai ANEKA dan Tri Hita Karana, sedangkan kuesioner digunakan untuk memperoleh hasil penilaian/respon para pakar dalam melakukan pengujian rancangan model evaluasi yang telah terbentuk. Disamping itu, kuesioner juga digunakan untuk mengumpulkan data simulasi yang nantinya akan diperuntukkan pada proses kalkulasi metode $S A W$ dalam penentuan aspek-aspek prioritas perbaikan.

Hasil penelitian ini dianalisis secara akurat menggunakan suatu teknik analisis yang sering disebut dengan deskriptif kuantitatif, dengan menggunakan pendekatan perhitungan deskriptif persentase untuk mendapatkan hasil persentase penilaian yang selanjutnya dapat digunakan sebagai dasar dalam melakukan penilaian atau penafsiran terhadap hasil uji coba model evaluasi yang dikembangkan. Perhitungan deskriptif persentase, dapat ditentukan dengan menggunakan formula sebagai berikut [11].

Persentase $=\frac{\sum(\text { Jawaban } x \text { Bobot Tiap Pilihan })}{\mathrm{n} \text { x Bobot Tertinggi }}$

Dimana:

$\sum=$ Jumlah

$\mathrm{n}=$ Jumlah seluruh item angket 
Adapun formula yang dapat digunakan untuk memproses perhitungan persentase keseluruhan subjek adalah sebagai berikut [12].

Persentase $=\frac{\text { F }}{\mathrm{N}} \times \frac{\mathrm{N}}{100 \%}$

Dimana:

$\mathrm{F}=$ Jumlah persentase keseluruhan subjek

$\mathrm{N}=$ banyaknya subjek

Untuk memudahkan dalam memaknai dan melakukan pengambilan suatu keputusan pada tingkat keakuratan dan efektivitas tercapainya suatu rancangan model evaluasi yang tepat setelah dilakukannya pengujian oleh pakar, maka hasil pengujian perlu dibandingkan dengan skala tingkat pencapaian efektivitas skala lima. Adapun skala tingkat pencapaian efektivitas dengan skala lima selengkapnya dapat dilihat pada Tabel 1 [11].

TABEL I

KonVERsi TiNGKAT PENCAPAIAN EFEKTIVITAS DENGAN SKALA LIMA

\begin{tabular}{|l|l|c|}
\hline $\begin{array}{c}\text { Tingkat } \\
\text { Pencapaian }\end{array}$ & \multicolumn{1}{|c|}{ Kategori } & Status Perbaikan \\
\hline $90-100$ & Sangat Baik & Tidak Perlu Perbaikan \\
\hline
\end{tabular}

\begin{tabular}{|l|l|l|}
\hline $\begin{array}{c}\text { Tingkat } \\
\text { Pencapaian }\end{array}$ & \multicolumn{1}{c|}{ Kategori } & \multicolumn{1}{c|}{ Status Perbaikan } \\
\hline $80-89$ & Baik & Tidak Perlu Perbaikan \\
\hline $65-79$ & Cukup & Perlu Perbaikan \\
\hline $55-64$ & Kurang & Perlu Perbaikan \\
\hline $0-54$ & Sangat Kurang & Perlu Perbaikan \\
\hline
\end{tabular}

\section{HASIL DAN PEMBAHASAN}

\section{A. Hasil}

Sesuai dengan tujuan penelitian dan fokus tahapan penelitian yang telah dijelaskan pada metode penelitian, maka beberapa hasil yang diperoleh dalam penelitian ini dapat dijelaskan sebagai berikut.

\section{1) Rancangan Model Evaluasi}

Berdasarkan tahapan model Borg and Gall yang telah dilakukan (khususnya pada tahapan desain), maka dalam penelitian ini diperoleh rancangan model evaluasi Stake berbasis ANEKA-Tri Hita Karana yang terintegrasi dengan perhitungan metode $S A W$. Adapun rancangan model yang dimaksudkan tersebut dapat dilihat pada Gambar 1.

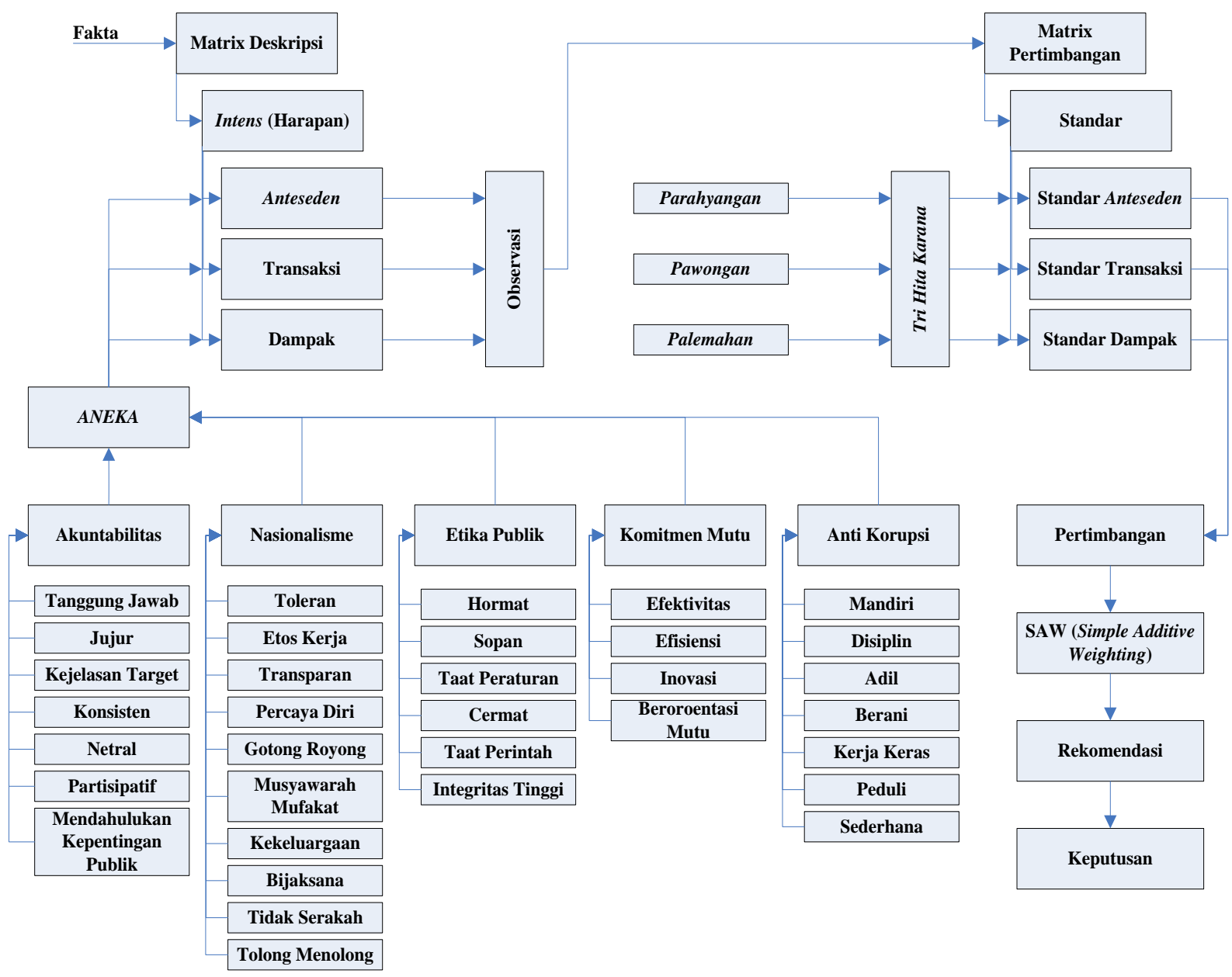

Gambar. 1 Rancangan model evaluasi Stake berbasis ANEKA-Tri Hita Karana yang terintegrasi dengan perhitungan metode SAW 
Berdasarkan gambar 1 di atas dapat dijelaskan bahwa model evaluasi Stake berbasis nilai ANEKA dan Tri Hita Karana yang digunakan dalam mengevaluasi karakter dan mutu belajar siswa SMK TI dalam mengikuti proses pembelajaran komputer memiliki dua tahapan evaluasi yaitu matrix deskripsi dan matrix pertimbangan. Terdapat dua komponen evaluasi pada matrix deskripsi antara lain: intens (harapan) dan observasi.

Komponen intens merupakan komponen yang menggambarkan tujuan yang diharapkan terjadi pada program yang dievaluasi berdasarkan tinjauan tiga hal utama yaitu anteseden, transaksi, dan dampak. Anteseden merujuk pada konteks yang diharapkan terjadi dalam suatu program, transaksi merujuk pada proses yang diharapkan dapat berjalan dengan baik dalam suatu program, dan dampak merujuk pada hasil dan efek yang diharapkan dapat terwujud dalam suatu program. Ketiga hal utama tersebut harus berdasarkan pada konsep ANEKA yang meliputi: akuntabilitas, nasionalisme, etika publik, komitmen mutu, dan anti korupsi. Pada bagian akuntabilitas, terdiri dari beberapa aspek yang digunakan untuk mengevaluasi mutu belajar dan karakter siswa dalam pembelajaran komputer, diantaranya: tanggung jawab, jujur, kejelasan target, konsisten, netral, partisipatif, dan mendahulukan kepentingan publik. Pada bagian nasionalisme terdiri dari beberapa aspek evaluasi, diantaranya: toleran, etos kerja, transparan, percaya diri, gotong royong, musyawarah mufakat, kekeluargaan, bijaksana, tidak serakah, dan tolong menolong. Pada bagian etika publik terdiri dari beberapa aspek evaluasi, diantaranya: hormat, sopan, taat pada peraturan perundang-undangan, cermat, taat perintah, dan integritas tinggi. Pada bagian komitmen mutu terdiri dari beberapa aspek evaluasi, diantaranya: efektivitas, efisiensi, inovasi, dan berorientasi mutu. Pada bagian anti korupsi terdiri dari beberapa aspek evaluasi, diantaranya: mandiri, disiplin, adil, berani, kerja keras, peduli, dan sederhana.

Komponen observasi merupakan suatu komponen yang digunakan untuk mengamati tujuan yang telah tercapai pada komponen intens (harapan). Hasil pengamatan dari komponen observasi tersebut kemudian dianalisis pada tahapan matrix pertimbangan. Pada matrix pertimbangan terdapat dua komponen yaitu standar dan pertimbangan. Komponen standar digunakan untuk menunjukkan adanya acuan mendasar dalam melakukan penilaian terhadap hasil pengamatan yang telah dilakukan sebelumnya pada komponen observasi. Standar yang terdapat pada matrix pertimbangan terdiri dari tiga bagian yaitu standar anteseden, standar transaksi, dan standar dampak. Ketiga standar tersebut harus mengacu pada nilai-nilai dasar yang terdapat pada konsep Tri Hita Karana, yang meliputi: Parahyangan, Palemahan, dan Pawongan. Komponen pertimbangan merupakan komponen evaluasi yang dipergunakan untuk memberikan suatu rekomendasi yang valid berdasarkan hasil observasi dan analisis antara masukan (input data) yang berupa fakta-fakta yang bersifat rasional yang telah dimasukkan sebelumnya pada komponen intens dibandingkan dengan standar dasar (minimal) yang tersedia pada komponen standar, sehingga nantinya dapat memudahkan para pengambil kebijakan dalam mengambil suatu keputusan yang terbaik berdasarkan rekomendasi yang diberikan. Rekomendasi tersebut diperoleh berdasarkan hasil perhitungan menggunakan metode $S A W$. Hasil perhitungan metode $S A W$ tersebut memberikan hasil berupa aspek-aspek yang menjadi prioritas perbaikan karakter siswa, sehingga nantinya dapat mudah memberikan rekomendasi untuk melakukan perbaikan terhadap sikap siswa dalam mengikuti pembelajaran komputer pada SMK TI.

\section{2) Uji Coba Rancangan Model Evaluasi}

Pada tahapan uji coba terhadap rancangan model evaluasi Stake berbasis ANEKA-Tri Hita Karana yang terintegrasi dengan perhitungan metode $S A W$ ini, melibatkan empat pakar yaitu dua orang pakar pendidikan dan dua orang pakar informatika. Adapun hasil uji coba rancangan model evaluasi tersebut, selengkapnya dapat ditunjukkan pada Tabel 2 .

TABEL II

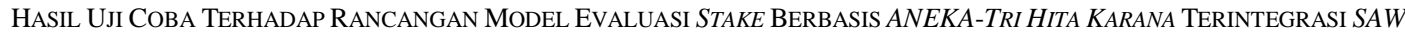

\begin{tabular}{|l|c|c|c|c|c|c|c|c|c|c|c|c|}
\hline \multirow{2}{*}{ Responden } & \multicolumn{10}{|c|}{ Butir- } & \multirow{2}{*}{$\begin{array}{c}\text { Efektivitas } \\
(\boldsymbol{\%})\end{array}$} \\
\cline { 2 - 15 } & $\mathbf{1}$ & $\mathbf{2}$ & $\mathbf{3}$ & $\mathbf{4}$ & $\mathbf{5}$ & $\mathbf{6}$ & $\mathbf{7}$ & $\mathbf{8}$ & $\mathbf{9}$ & $\mathbf{1 0}$ & & 88 \\
\hline Pakar Informatika Ke-1 & 5 & 5 & 4 & 5 & 4 & 4 & 5 & 4 & 4 & 4 & 44 & 88 \\
\hline Pakar Informatika Ke-2 & 4 & 4 & 4 & 5 & 5 & 4 & 5 & 5 & 4 & 5 & 45 & 90 \\
\hline Pakar Pendidikan Ke-1 & 4 & 4 & 4 & 4 & 5 & 5 & 4 & 4 & 5 & 4 & 43 & 86 \\
\hline Pakar Pendidikan Ke-2 & 5 & 4 & 5 & 4 & 5 & 4 & 4 & 5 & 5 & 5 & 46 & 92 \\
\hline
\end{tabular}

Berdasarkan hasil yang ditunjukkan pada Tabel 2 di atas, terlihat bahwa rata-rata keefektifan rancangan model evaluasi Stake berbasis nilai ANEKA-Tri Hita Karana yang terintegrasi dengan perhitungan metode $S A W$ sebesar $89 \%$, sehingga jika dianalisis dengan menggunakan tabel konversi tingkat pencapaian efektivitas dengan skala lima yang telah ditunjukkan sebelumnya pada Tabel 1, maka rancangan model evaluasi ini termasuk dalam kategori baik.

Kendatipun secara umum model evaluasi yang dikembangkan ini termasuk dalam kategori baik, namun ada beberapa saran yang diberikan oleh para pakar sebagai penyempurnaan terhadap model evaluasi ini agar lebih optimal. Adapun beberapa saran yang diberikan oleh para pakar selengkapnya dapat dilihat pada Tabel III. 
TABEL III

SARAN PAKAR TERHADAP RANCANGAN MODEL EVALUASI

\begin{tabular}{|c|l|l|}
\hline No. & \multicolumn{1}{|c|}{ Pakar } & \multicolumn{1}{c|}{ Saran } \\
\hline 1 & Pakar Informatika Ke-1 & $\begin{array}{l}\text { Formula } S A W \text { perlu } \\
\text { ditampilkan dalam desain }\end{array}$ \\
\hline 2 & Pakar Informatika Ke-2 & - \\
\hline 3 & Pakar Pendidikan Ke-1 & - \\
\hline 4 & Pakar Pendidikan Ke-2 & $\begin{array}{l}\text { Perlu ditampilkan } \\
\text { formula } S A W \text { yang } \\
\text { digunakan untuk } \\
\text { menentukan aspek-aspek } \\
\text { prioritas perbaikan } \\
\text { karakter }\end{array}$ \\
\hline
\end{tabular}

Berdasarkan hasil yang ditunjukkan pada Tabel III tersebut, maka terbukti secara umum tidak perlu melakukan revisi mayor terhadap rancangan model Stake berbasis nilai ANEKA-Tri Hita Karana yang terintegrasi dengan perhitungan metode $S A W$. Hanya saja saran yang diberikan tersebut perlu dipertimbangkan untuk dapat dilaksanakan, sehingga nantinya model evaluasi ini dapat berjalan lebih optimal serta menghasilkan rekomendasi yang pantas dan baik demi peningkatan karakter dan mutu belajar siswa SMK TI dalam mengikuti proses pembelajaran komputer.

\section{3) Simulasi Perhitungan Metode SAW (Simple Additive Weighting)}

Simulasi proses perhitungan metode $S A W$ yang dapat digunakan untuk menentukan aspek-aspek yang menjadi prioritas perbaikan terhadap karakter siswa menggunakan data yang diperoleh dari pengisian kuesioner simulasi yang dilakukan oleh keempat pakar. Adapun data simulasi yang dimaksudkan dapat ditunjukkan pada Tabel IV.

TABEL IV

Data untuK Simulasi PeRhitungan Metode SAW

\begin{tabular}{|c|c|c|c|c|c|c|c|c|c|c|c|c|c|c|c|c|c|c|c|c|c|c|c|c|c|c|}
\hline \multirow{3}{*}{\multicolumn{2}{|c|}{ Aspek-aspek Tri Hita Karana }} & \multicolumn{25}{|c|}{ Komponen $A N E K A$} \\
\hline & & \multicolumn{5}{|c|}{ Akuntabilitas } & \multicolumn{5}{|c|}{ Nasionalisme } & \multicolumn{5}{|c|}{ Etika Publik } & \multicolumn{5}{|c|}{ Komitmen Mutu } & \multicolumn{5}{|c|}{ Anti Korupsi } \\
\hline & & \multirow[t]{2}{*}{ P1 } & \multirow[t]{2}{*}{$\mathbf{P 2}$} & \multirow[t]{2}{*}{ P3 } & \multirow[t]{2}{*}{ P4 } & \multirow[t]{2}{*}{$\begin{array}{c}\text { Rata- } \\
\text { rata }\end{array}$} & \multirow[t]{2}{*}{ P1 } & \multirow[t]{2}{*}{$\mathbf{P 2}$} & \multirow[t]{2}{*}{ P3 } & \multirow[t]{2}{*}{$\mathbf{P 4}$} & \multirow[t]{2}{*}{$\begin{array}{c}\text { Rata- } \\
\text { rata }\end{array}$} & \multirow[t]{2}{*}{ P1 } & \multirow[t]{2}{*}{$\mathbf{P 2}$} & \multirow[t]{2}{*}{ P3 } & \multirow[t]{2}{*}{ P4 } & \multirow[t]{2}{*}{$\begin{array}{c}\text { Rata- } \\
\text { rata } \\
\end{array}$} & \multirow[t]{2}{*}{ P1 } & \multirow[t]{2}{*}{ P2 } & \multirow[t]{2}{*}{ P3 } & \multirow[t]{2}{*}{ P4 } & \multirow[t]{2}{*}{\begin{tabular}{c|} 
Rata- \\
rata
\end{tabular}} & \multirow[t]{2}{*}{ P1 } & \multirow[t]{2}{*}{ P2 } & P3 & P4 & $\begin{array}{c}\text { Rata- } \\
\text { rata }\end{array}$ \\
\hline $\mathbf{a}$ & Parahyangan & & & & & & & & & & & & & & & & & & & & & & & & & \\
\hline a1 & $\begin{array}{l}\text { Mempertahankan budaya } \\
\text { rajin sembahyang }\end{array}$ & 5 & 4 & 4 & 5 & 4,50 & 4 & 4 & 3 & 4 & 3,75 & 4 & 3 & 4 & 4 & 3,75 & 4 & 5 & 4 & 4 & 4,25 & 4 & 4 & 5 & 4 & 4,25 \\
\hline a2 & $\begin{array}{l}\text { Toleransi cara } \\
\text { sembahyang diantara } \\
\text { siswa kendatipun } \\
\text { berbeda-beda agama }\end{array}$ & 4 & 5 & 4 & 4 & 4,25 & 3 & 4 & 5 & 4 & 4,00 & 5 & 4 & 5 & 3 & 4,25 & 4 & 4 & 3 & 4 & 3,75 & 4 & 3 & 4 & 4 & 3,75 \\
\hline $\mathbf{b}$ & Pawongan & & & & & & & & & & & & & & & & & & & & & & & & & \\
\hline b1 & Bekerjasama & 5 & 4 & 5 & 3 & 4,25 & 4 & 5 & 4 & 4 & 4,25 & 4 & 5 & 4 & 4 & 4,25 & 4 & 4 & 3 & 5 & 4,00 & 4 & 4 & 3 & 4 & 3,75 \\
\hline $\mathrm{b} 2$ & $\begin{array}{l}\text { Berusaha memahami } \\
\text { karakter orang lain }\end{array}$ & 4 & 3 & 3 & 4 & 3,50 & 4 & 3 & 4 & 4 & 3,75 & 4 & 3 & 4 & 4 & 3,75 & 4 & 5 & 4 & 4 & 4,25 & 4 & 4 & 4 & 5 & 4,25 \\
\hline b3 & $\begin{array}{l}\text { Saling menjaga } \\
\text { kenyamanan dan } \\
\text { ketertiban proses } \\
\text { pembelajaran }\end{array}$ & 5 & 4 & 5 & 4 & 4,50 & 4 & 3 & 4 & 3 & 3,50 & 4 & 5 & 4 & 4 & 4,25 & 4 & 4 & 3 & 4 & 3,75 & 5 & 4 & 3 & 4 & 4,00 \\
\hline b4 & Saling menghormati & 4 & 3 & 4 & 4 & 3,75 & 4 & 5 & 4 & 4 & 4,25 & 5 & 4 & 4 & 4 & 4,25 & 4 & 4 & 4 & 3 & 3,75 & 4 & 5 & 4 & 4 & 4,25 \\
\hline c & Palemahan & & & & & & & & & & & & & & & & & & & & & & & & & \\
\hline $\mathrm{c} 1$ & $\begin{array}{l}\text { Menjaga keutuhan dan } \\
\text { kebersihan fasilitas- } \\
\text { fasilitas yang ada di } \\
\text { sekolah }\end{array}$ & 4 & 5 & 4 & 4 & 4,25 & 5 & 4 & 5 & 4 & 4,50 & 4 & 3 & 4 & 4 & 3,75 & 4 & 3 & 4 & 4 & 3,75 & 4 & 3 & 3 & 4 & 3,50 \\
\hline $\mathrm{c} 2$ & $\begin{array}{l}\text { Menjaga kebersihan } \\
\text { lingkungan sekolah }\end{array}$ & 4 & 5 & 5 & 4 & 4,50 & 4 & 4 & 3 & 4 & 3,75 & 4 & 4 & 5 & 4 & 4,25 & 5 & 4 & 3 & 4 & 4,00 & 3 & 4 & 4 & 4 & 3,75 \\
\hline
\end{tabular}

Keterangan: P1 = Pakar Informatika Ke-1; P2 = Pakar Informatika Ke-2; P3 = Pakar Pendidikan Ke-1; P4 = Pakar Pendidikan Ke-2

Sebelum lebih lanjut melakukan perhitungan, maka sebelumnya perlu diketahui sekilas tentang metode $S A W$. Konsep dasar metode $S A W$ adalah mencari penjumlahan terbobot dari rating kinerja pada setiap alternatif pada semua atribut. Metode $S A W$ membutuhkan proses normalisasi matriks keputusan (X) ke suatu skala yang dapat diperbandingkan dengan semua rating alternatif yang ada [13],[14],[15],[16]. Formula untuk melakukan normalisasi tersebut adalah sebagai berikut:

$$
r_{i j}= \begin{cases}\frac{x_{i j}}{\operatorname{Maxx}_{i j}} & j i k a \mathrm{j} \text { adalah atribut keuntungan (benefit) } \\ \frac{\operatorname{Min}_{i} x_{i j}}{x_{i j}} & \text { jika } \mathrm{j} \text { adalah atribut biaya (cost) }\end{cases}
$$

$\mathrm{r}_{\mathrm{ij}}$ adalah rating kinerja ternormalisasi dari alternatif $\mathrm{A}_{\mathrm{i}}$ pada atribut $\mathrm{C}_{\mathrm{j}} ; \mathrm{i}=1,2, \ldots, \mathrm{m}$ dan $\mathrm{j}=1,2, \ldots, \mathrm{n}$.

Nilai preferensi untuk setiap alternatif $\left(\mathrm{V}_{\mathrm{i}}\right)$ diberikan sebagai berikut [17],[18],[19]:

$$
V_{i}=\sum_{j=1}^{n} w_{j} r_{i j}
$$

Dimana: $\mathrm{w}_{\mathrm{j}}=$ nilai bobot tiap kriteria

$$
\mathrm{r}_{\mathrm{ij}}=\text { nilai rating kinerja yang ternormalisasi }
$$

Nilai $V_{i}$ yang lebih besar mengindikasikan bahwa alternatif $\mathrm{A}_{\mathrm{i}}$ lebih terpilih. Adapun penjelasan lengkap tentang proses perhitungan penentuan aspek-aspek yang menjadi prioritas perbaikan karakter siswa dapat dijelaskan sebagai berikut. 
a) Perhitungan Normalisasi

Berdasarkan data yang ditunjukkan pada table IV dan mempertimbangkan bahwa semua komponen ANEKA termasuk dalam atribut keuntungan, maka selanjutnya dapat dilakukan proses perhitungan normalisasi sebagai berikut.

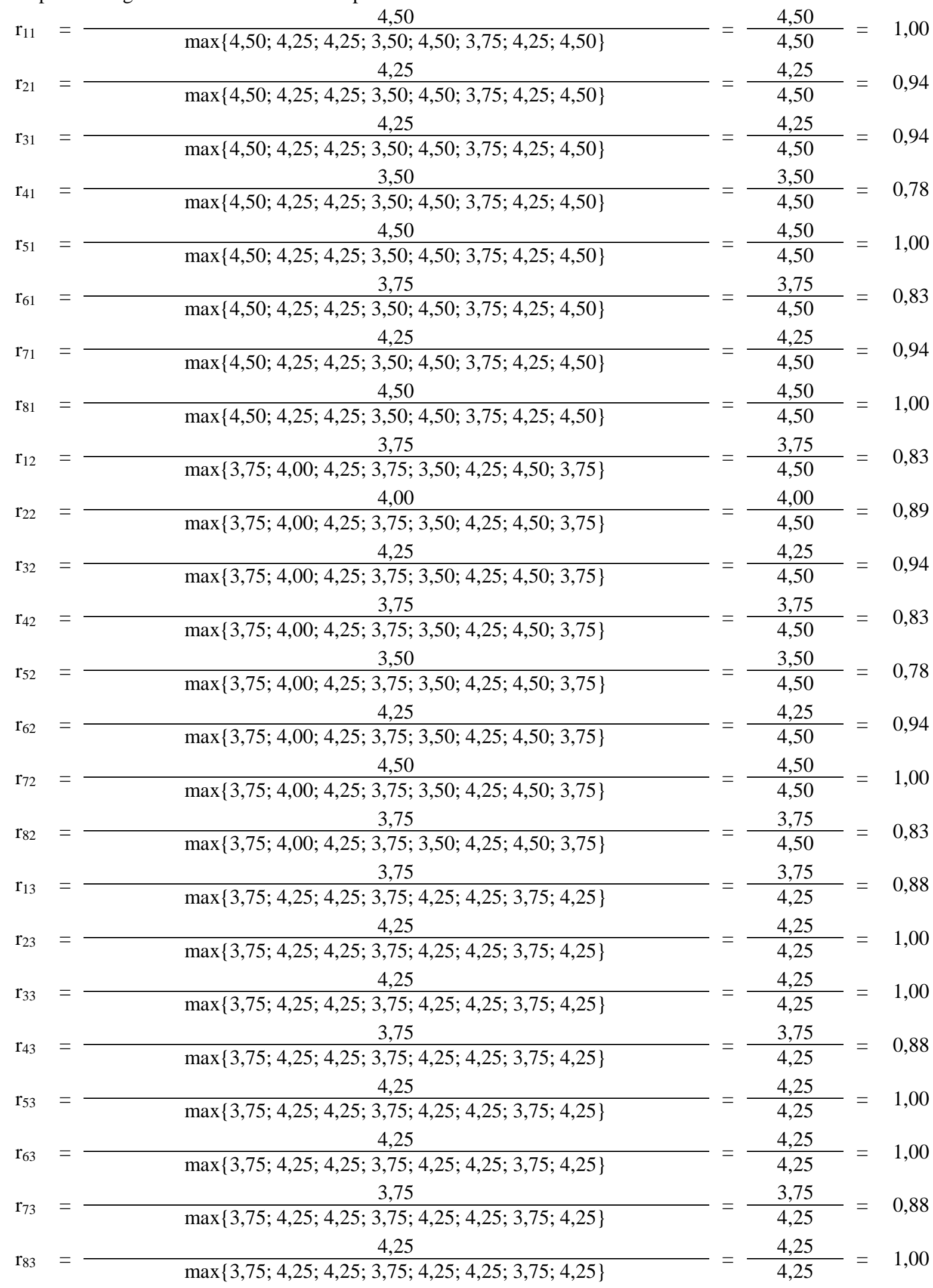




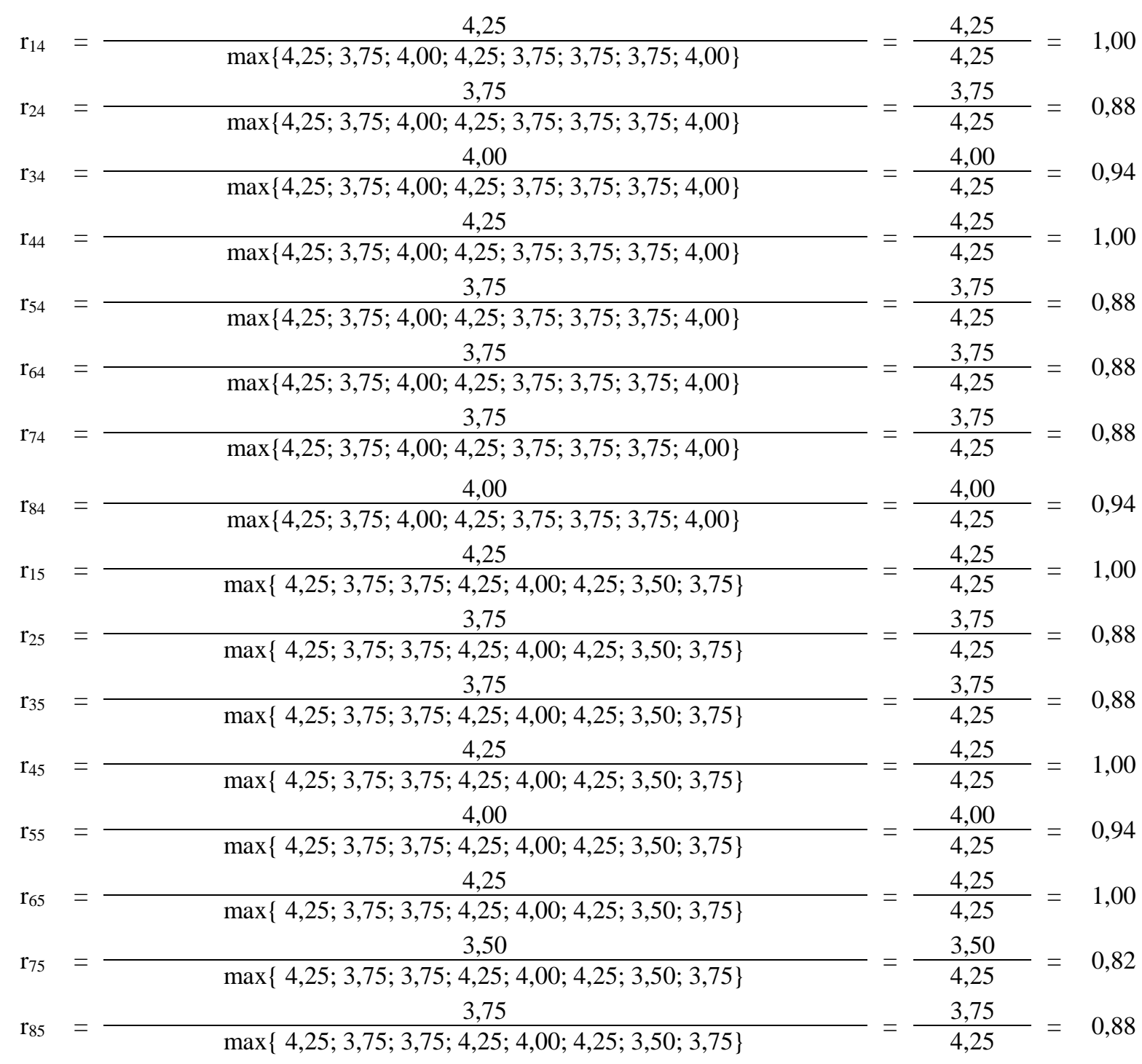

b) Penentuan Matrix $\mathrm{R}$

Berdasarkan hasil normalisasi tersebut, maka selanjutnya dilakukan pengkonversian setiap nilai ternormalisasi ke dalam matrix $\mathrm{R}$ berikut ini.

$\mathbf{R}=\left(\begin{array}{lllll}1,00 & 0,83 & 0,88 & 1,00 & 1,00 \\ 0,94 & 0,89 & 1,00 & 0,88 & 0,88 \\ 0,94 & 0,94 & 1,00 & 0,94 & 0,88 \\ 0,78 & 0,83 & 0,88 & 1,00 & 1,00 \\ 1,00 & 0,78 & 1,00 & 0,88 & 0,94 \\ 0,83 & 0,94 & 1,00 & 0,88 & 1,00 \\ 0,94 & 1,00 & 0,88 & 0,88 & 0,82 \\ 1,00 & 0,83 & 1,00 & 0,94 & 0,88\end{array}\right.$

c) Perankingan

Langkah selanjutnya adalah melakukan proses perankingan menggunakan data dari matrik $\mathrm{R}$ dan bobot pengambil keputusan untuk masing-masing komponen ANEKA dengan rincian sebagai berikut:

- Bobot untuk komponen akuntabilitas $=20 \%$

- Bobot untuk komponen nasionalisme $=20 \%$

- Bobot untuk komponen etika publik $=20 \%$
- Bobot untuk komponen komitmen mutu $=20 \%$

- Bobot untuk komponen anti korupsi $=20 \%$

Adapun proses perhitungan perankingan tersebut, selengkapnya dapat dijelaskan sebagai berikut. $\mathrm{V}_{1}=(0,20)(1,00)+(0,20)(0,83)+(0,20)(0,88)+$ $(0,20)(1,00)+(0,20)(1,00)=0,9431$

$\mathrm{V}_{2}=(0,20)(0,94)+(0,20)(0,89)+(0,20)(1,00)+$ $(0,20)(0,88)+(0,20)(0,88)=0,9196$

$\mathrm{V}_{3}=(0,20)(0,94)+(0,20)(0,94)+(0,20)(1,00)+$ $(0,20)(0,94)+(0,20)(0,88)=0,9425$

$\mathrm{V}_{4}=(0,20)(0,78)+(0,20)(0,83)+(0,20)(0,88)+$ $(0,20)(1,00)+(0,20)(1,00)=0,8987$

$\mathrm{V}_{5}=(0,20)(1,00)+(0,20)(0,78)+(0,20)(1,00)+$ $(0,20)(0,80)+(0,20)(1,00)=0,9203$

$\mathrm{V}_{6}=(0,20)(0,83)+(0,20)(0,94)+(0,20)(1,00)+$ $(0,20)(0,88)+(0,20)(1,00)=0,9320$

$\mathrm{V}_{7}=(0,20)(0,94)+(0,20)(1,00)+(0,20)(0,88)+$ $(0,20)(0,88)+(0,20)(0,82)=0,9065$

$\mathrm{V}_{8}=(0,20)(1,00)+(0,20)(0,83)+(0,20)(1,00)+$ $(0,20)(0,94)+(0,20)(0,88)=0,9314$ 


\section{d) Penentuan Keputusan}

Dari hasil perangkingan tersebut, maka ditemukan aspek karakter yang perlu menjadi prioritas perbaikan adalah V4 (aspek "berusaha memahami karakter orang lain" yang terdapat pada salah satu bagian dari konsep Tri Hita Karana yaitu pawongan). Disamping itu juga jika merujuk dari aspek V4 yang menjadi aspek prioritas dalam menunjang peningkatan karakter, maka komponen penentu mutu belajar siswa dalam proses pembelajaran komputer yang perlu menjadi prioritas adalah nasionalisme, komitmen mutu, dan anti korupsi (yang terdapat pada komponen $A N E K A)$.

\section{B. Pembahasan}

Pada bagian ini secara khusus dibahas beberapa hal yang belum dijelaskan secara mendalam pada hasil penelitian. Adapun beberapa hal tersebut adalah sebagai berikut.

Konsep ANEKA dan Tri Hita Karana yang digunakan menjadi dasar dalam penentuan aspek-aspek evaluasi pada model evaluasi Stake berbasis ANEKA-Tri Hita Karana yang terintegrasi dengan perhitungan metode $S A W$. Konsep ANEKA pada dasarnya merupakan kependekan dari kata "Akutabilitas", "Nasionalisme", "Etika Publik", "Komitmen Mutu”, dan "Anti Korupsi” [20],[21]. ANEKA merupakan suatu nilai-nilai yang harus mampu diinternalisasikan secara baik dan optimal oleh para pegawai negeri sipil dalam melaksanakan tugasnya, sehingga dapat menunjukkan tingkat profesionalisme mereka. Jika dikaitkan dengan penelitian ini maka konsep ANEKA juga dapat digunakan untuk mengukur mutu belajar siswa dalam proses pembelajaran komputer pada SMK TI.

Konsep Tri Hita Karana pada dasarnya mempunyai arti sebagai tiga penyebab kebahagiaan bagi manusia yang disebabkan karena manusia mampu menjaga hubungan yang harmonis dengan Tuhan (Parahyangan), mampu menjaga hubungan yang harmonis dengan sesamanya (Pawongan), dan mampu menjaga hubungan yang harmonis dengan alam yang ada disekitarnya (Palemahan) [22],[23]. Jika dikaitkan dengan penelitian ini maka konsep Tri Hita Karana dapat digunakan sebagai dasar dalam melakukan pengukuran terhadap karakter siswa SMK TI dalam mengikuti proses pembelajaran.

Rata-rata persentase efektivitas sebesar $89.00 \%$ yang diperoleh melalui uji coba rancangan model evaluasi yang telah ditunjukkan sebelumnya pada Tabel II dan jika dibandingkan dengan konversi tingkat pencapaian efektivitas skala lima yang ditunjukkan pada Tabel I, maka dapat dikatakan bahwa rancangan model evaluasi Stake berbasis ANEKA-Tri Hita Karana yang terintegrasi dengan perhitungan metode $S A W$ sudah termasuk dalam kategori baik, sehingga tidak perlu dilakukan perbaikan secara menyeluruh terhadap rancangan model tersebut. Kendatipun demikian, beberapa saran yang telah diberikan oleh para pakar adalah sangat baik untuk penyempurnaan rancangan model evaluasi ke arah yang lebih baik terutama dalam hal pengadopsian metode $S A W$
(Simple Additive Weighting), sehingga memudahkan model evaluasi ini dalam menentukan aspek-aspek yang menjadi prioritas perbaikan/penyempurnaan dalam rangka mewujudkan peningkatan karakter positif siswa dan mutu belajar siswa dalam pembelajaran komputer pada SMK TI di Provinsi Bali.

Hasil simulasi perhitungan metode SAW (Simple Additive Weighting) yang telah ditunjukkan sebelumnya sudah mampu menunjukkan akurasi yang tinggi dalam menentukan aspek-aspek yang menjadi prioritas perbaikan. Aspek prioritas dalam mewujudkan peningkatan karakter ditentukan berdasarkan nilai minimum pada aspek Tri Hita Karana, sedangkan komponen yang menjadi prioritas dalam mewujudkan peningkatan kualitas pembelajaran siswa SMK TI ditentukan berdasarkan nilai minimum pada komponen ANEKA yang diintegrasikan dari perolehan nilai minimum aspek Tri Hita Karana.

Penelitian ini merupakan solusi yang efektif untuk menjawab beberapa kelemahan yang ditemukan pada penelitian sebelumnya yang dilakukan pada tahun 2017 oleh Retnowati, dkk [8], serta penelitian pada tahun 2015 oleh Sugiyanto, Kartowagiran, dan Jailani [9]. Adapun solusi tersebut yaitu dengan menunjukkan inovasi model evaluasi Stake berbasis ANEKA-Tri Hita Karana dan diintegrasikan dengan perhitungan metode $S A W$ yang mampu menunjukkan secara rinci aspek-aspek yang digunakan untuk mengevaluasi kemampuan kognitif siswa sehingga dapat diketahui tingkat mutu belajar siswa dalam proses pembelajaran komputer, dan mengevaluasi sikap siswa sehingga dapat diketahui peningkatan karakter positif siswa.

Penelitian ini juga berhasil menjawab kendala penelitian yang dilakukan Puspayanti pada tahun 2018[24] yaitu dengan menunjukkan proses perhitungan $S A W$ dalam menentukan aspek-aspek evaluasi yang menjadi prioritas perbaikan. Hal ini menunjukkan bahwa penelitian ini telah berkontribusi dalam memecahkan kendala dalam penelitian Puspayanti tersebut, dimana dalam penelitian Puspayanti belum menunjukkan aspekaspek evaluasi yang menjadi prioritas perbaikan dalam komponen anteseden, transaksi, dan dampak. Penelitian Puspayanti hanya menunjukkan tingkat persentase efektivitas hasil evaluasi pembelajaran diklat pada komponen anteseden, transaksi, dan dampak.

Penelitian ini berhasil menjadi solusi pemecahan kendala penelitian Mania dan Hasaruddin tahun 2018 [25] yaitu dengan menunjukkan pemanfaatan metode $S A W$ dalam menunjukkan aspek-aspek dominan yang menjadi prioritas perbaikan/penyempurnaan. Kendala penelitian Mania dan Hasaruddin adalah belum menunjukkan aspekaspek dan komponen evaluasi yang menjadi prioritas perbaikan. Penelitian Mania dan Hasaruddin hanya mampu menunjukkan pengkategorian hasil evaluasi program pelatihan pembangunan karakter pada tahapan anteseden, tahapan transaksi, dan tahapan dampak. Berdasarkan hal tersebut, maka tampak jelas bahwa penelitian ini memiliki kontribusi penting sebagai solusi atas kendala penelitian Mania dan Hasaruddin. 
Solusi-solusi yang telah dijelaskan tersebutlah menjadi pembeda sekaligus keunggulan/kebaruan dari penelitian ini jika dibandingkan dengan penelitian-penelitian sebelumnya. Kebaruannya ialah terkait dengan adanya suatu model evaluasi yang tepat digunakan untuk menentukan aspek-aspek dominan evaluasi yang menjadi prioritas perbaikan dengan menerapkan konsep evaluasi pendidikan, konsep kearifan lokal Bali, serta salah satu metode sistem pendukung keputusan dalam rangka mengevaluasi karakter siswa dan mutu belajar siswa dalam proses pembelajaran komputer (khususnya pada SMK TI). Kendatipun penelitian ini memiliki keunggulan, namun kenyataannya masih ada kendala yang ditemukan yaitu proses perhitungannya masih terbatas hanya menggunakan satu metode saja yaitu $S A W$, padahal jika digabungkan dengan metode lainnya akan mendapat hasil yang lebih akurat dan optimal.

\section{KESIMPULAN}

Rancangan model evaluasi Stake berbasis ANEKA-Tri Hita Karana yang terintegrasi dengan perhitungan metode $S A W$ ini sudah dibuat dengan baik dan teruji oleh para pakar yang kompeten baik di bidang informatika maupun pendidikan, sehingga secara umum tingkat efektivitasnya tergolong baik karena sudah mampu menggabungkan konsep model evaluasi Stake, konsep ANEKA, dan konsep Tri Hita Karana secara komperehensif. Model ini juga menyisipkan metode SAW (Simple Additive Weighting) untuk memudahkan dalam proses perhitungan penentuan aspek-aspek yang menjadi prioritas perbaikan, sehingga nantinya dapat mengoptimalkan proses evaluasi terhadap kemampuan kognitif dan karakter siswa SMK TI yang mengikuti proses pembelajaran komputer. Rekomendasi yang dapat ditawarkan untuk memecahkan kendala yang ditemukan dalam penelitian ini adalah dengan mengkombinasikan metode $S A W$ dengan metode sistem pendukung keputusan lainnya, sehingga nantinya mampu menghasilkan perhitungan yang lebih akurat dari hasil perhitungan sebelumnya.

\section{UCAPAN TERIMA KASIH}

Penulis menyampaikan ucapan terima kasih kepada Rektor dan Ketua Lembaga Penelitian dan Pengabdian Kepada Masyarakat Universitas Pendidikan Ganesha yang telah berkenan memberikan ijin dan kesempatan kepada penulis dalam menyelesaikan dan mempublikasikan hasil penelitian ini.

\section{REFERENSI}

[1] Usman, "Dinamika Pembelajaran Berbasis Teknologi Informasi Pada Lembaga Pendidikan Tinggi," Jurnalisa, Vol. 3, No.1, 61-75, 2017.

[2] I.M. Sundayana, "Implementation of Computer Assisted CIPP Model for Evaluation Program of HIV/AIDS Countermeasures in Bali," International Journal of Advanced Research in Artificial Intelligence, Vol. 4, No. 11, 27-29, 2015.

[3] B. Mahirah, "Evaluasi Belajar Peserta Didik (Siswa)," Jurnal Idaarah, Vol. 1, No. 2, 257-267, 2017.

[4] M. Prihaswati, E.A. Purnomo, Sukestiyarno, and Mulyono, "UCLA Method: The Character Education Evaluation on Basic
Mathematics Learning in Higher Education," The $3^{\text {rd }}$ International Seminar on Education and Technology, 55-60, 2017.

[5] T.J. Gondikit, "The Evaluation of Post PT3 Program Using Stake's Countenance Model," Malaysian Journal of Social Sciences and Humanities (MJ-SSH), Vol. 3, No. 4, 109-118, 2018.

[6] A. Lukum, "Evaluasi Program Pembelajaran IPA SMP Menggunakan Model Countenance Stake," Jurnal Penelitian dan Evaluasi Pendidikan, Vol. 19, No. 1, 25-37, 2015.

[7] P.S. Oktarina, "Aktualisasi Nilai ANEKA Pada Profesi Dosen IHDN Denpasar Sebagai Dasar Komitmen Mutu Pelayanan Publik," Jurnal Penjaminan Mutu, Vol. 2, No.1, 28-33, 2016.

[8] T.H. Retnowati, D. Mardapi, B. Kartowagiran, dan Suranto, "Model evaluasi kinerja Dosen: Pengembangan Instrumen Untuk Mengevaluasi Kinerja Dosen," Jurnal Penelitian dan Evaluasi Pendidikan, Vol.21, No.2, 206-214, 2017

[9] Sugiyanto, B. Kartowagiran, dan Jailani, "Pengembangan Model Evaluasi Proses Pembelajaran Matematika di SMP Berdasarkan Kurikulum 2013," Jurnal Penelitian dan Evaluasi Pendidikan. Vol.19, No.1, 82-95, 2015

[10] A. Basuki, "Efektifitas Implementasi Diklat Prajabatan Kategori I dan II Sesuai Peraturan Kepala LAN Nomor 18 Tahun 2014," Prosiding Pertemuan Ilmiah Tahunan (PIT) Nasional ke-2 Ikatan Widyaiswara Indonesia (IWI) Provinsi Banten Pandeglang, 484491, 2015.

[11] W. Ramansyah, "Pengembangan Multimedia Pembelajaran Interaktif dengan Tema Pengenalan Huruf Hijaiyah untuk Peserta Didik Sekolah Dasar," Jurnal Ilmiah Edutic, Vol. 3, No. 1, 28-37, 2016.

[12] Y. Maryansyah, "An Analysis on Readability of English Reading Texts for Grade IX Students at MTSN 2 Kota Bengkulu," Premise Journal, Vol. 5, No.1, 69-88, 2016.

[13] D.Y.H. Tanjung, and R. Adawiyah, "Optimizing Selection of Decision Support System with Fuzzy Simple Additive Weighting," The $6^{\text {th }}$ International Conference on Cyber and IT Service Management (CITSM 2018), 1-4, 2018.

[14] G. Lumbantoruan, M.J. Purba, E.J.G. Harianja, R. Nainggolan, R Perangin-angin, and D. Manalu, "Determines the Weight Criteria of Simple Additive Weighting Method Using Certainty Factor," 2019 International Conference of Computer Science and Information Technology (ICoSNIKOM), 1-5, 2019.

[15] D.B. Sanjaya, Sukadi, N. Suastika, Y. Sastrawijaya, and I.G.A.P Kartika, "Utilization of Civic KVS-SAW Evaluation Model in Determining the Effectiveness of Tri Hita Karana in Character Education for Students on Elementary School of Bali Aga," Journal of Engineering and Applied Sciences, Vol. 14, No. 8, 2572-2581, 2019.

[16] E. Siswanto, and A.W. Katili, "Implementation of Decision Support System for Campus Promotion Management using Fuzzy Multiple Analytic Decision Making (FMADM) Method (Case Study: Universitas Multimedia Nusantara)," $4^{\text {th }}$ International Conference on New Media Studies, 75-80, 2017.

[17] J. Kittur, "Optimal Generation Evaluation using SAW, WP, AHP and PROMETHEE Multi - Criteria Decision Making Techniques," 2015 IEEE International Conference on Technological Advancements in Power \& Energy, 304-309, 2015.

[18] B.C. Cuong, N.T. Lich, and D.T. Ha, "Combining Fuzzy Set Simple Additive Weight and Comparing with Grey Relational Analysis for Student's Competency Assessment in the Industrial 4.0," $10^{\text {th }}$ International Conference on Knowledge and Systems Engineering (KSE), 294-299, 2018.

[19] Irvanizam, "Multiple Attribute Decision Making with Simple Additive Weighting Approach for Selecting the Scholarship Recipients at Syiah Kuala University," 2017 International Conference on Electrical Engineering and Informatics (ICELTICs 2017), 245-250, 2017.

[20] T.N. Haryani, dan O.H. Nurcahyono, "Knowledge, Attitude, Practice (KAP) Aparatur Sipil Negara dalam Implementasi Nilai Dasar Pegawai," Jurnal SAWALA, Vol. 6, No.1, 73-81, 2018.

[21] A. Subekan, dan A. Iskandar. "Pengaruh Pemahaman Nilai Dasar 'ANEKA' Terhadap Pembentukan Sikap Peserta Latsar CPNS Pada Balai Diklat Keuangan Malang," Jurnal Pendidikan, Vol. 20, No. 2, 91-110, 2019 
[22] H. Perbowosari, "The Local Wisdom Value of Mandhasiya Tradition (Study of Hindu Education)," Vidyottama Sanatana: International Journal of Hindu Science and Religious Studies, Vol. 3, No. 1, 1-12, 2019.

[23] J. Ishwari, S. Wahyuni, I. Heruwasto, A.W. Widjaja, and E.N. Kencana, "Do Local Values Affect Performances? The Study of Tri Hita Karana Culture on Hotel Performance in Bali," $12^{\text {th }}$ International Conference on Business and Management Research (ICBMR 2018), 196-203, 2018.

[24] A. Puspayanti, "Evaluasi Pembelajaran Diklat Menggunakan Model Countenance Stake," Andragogi Jurnal Diklat Teknis Pendidikan dan Keagamaan, Vol.6, No.1, 143-167, 2018.

[25] S. Mania, dan Hasaruddin, "Evaluasi Pelaksanaan Program Character Building Training di Universitas Islam Negeri Alauddin Makassar," Islamic Counseling: Jurnal Bimbingan dan Konseling Islam, Vol. 2, No. 1, 1-20, 2018 